\title{
REJONOWY OŚRODEK PRACY PARTYJNEJ W RADZYNIU PODLASKIM (1982-1989) - ELEMENT STRUKTURY ORGANIZACYJNEJ PZPR, AKTOTWÓRCA, ZESPÓŁ ARCHIWALNY
}

\section{Słowa kluczowe}

Polska Zjednoczona Partia Robotnicza; Rejonowy Ośrodek Pracy Partyjnej w Radzyniu Podlaskim; akta PZPR; zespół Rejonowego Ośrodka Pracy Partyjnej w Radzyniu Podlaskim; Radzyń Podlaski

\section{Keywords}

Polish United Workers' Party; Local Party Labor Center in Radzyń Podlaski; records of Polish communist party; archival fonds of Local Party Labor Center in Radzyń Podlaski

\section{Streszczenie}

Rejonowe ośrodki pracy partyjnej powołano do istnienia w styczniu 1982 r., co wiązało się z przegrupowaniem i uporządkowaniem zadań Polskiej Zjednoczonej Partii Robot-

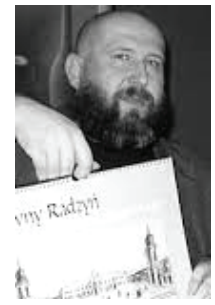

Dariusz Magier, profesor nadzwyczajny w Instytucie Historii i Stosunków Międzynarodowych Uniwersytetu Przyrodniczo-Humanistycznego w Siedlcach, dyrektor Oddziału IPN w Lublinie. Jego zainteresowania naukowe to teoria i metodyka archiwalna, kancelaria XX w., dzieje biurokracji komunistycznej, historia najnowsza Podlasia. Jest autorem m.in. monografii System biurokratyczny Polskiej Zjednoczonej Partii Robotniczej w województwie bialskopodlaskim w latach 1975-1990 (Siedlce 2013). E-mail: dmagier@archiwozofia.com. 
niczej (PZPR), związanych z nową sytuacją społeczno-polityczną po wprowadzeniu stanu wojennego w Polsce. Artykuł prezentuje ten element rozbudowanej struktury biurokratycznej sprawującej dyktatorską władzę partii poprzez archiwalne opisanie jego dziejów ustrojowych oraz spuścizny dokumentacyjnej. Przykład laboratoryjny opisu stanowi Rejonowy Ośrodek Pracy Partyjnej (ROPP) w Radzyniu Podlaskim. Autor podejmuje zadanie określenia, czym był ten twór w organizacji partii komunistycznej w Polsce, charakterystyczny dla ostatniej dekady jej istnienia. ROPP nie wchodziły w skład wybieralnych organów statutowych PZPR, lecz stanowiły biurokratyczną strukturę doradczo-koordynacyjną wobec podstawowych szczebli partii komunistycznej. ROPP w Radzyniu Podlaskim był jednym z czterech utworzonych w województwie bialskopodlaskim, a obszar ich działania odpowiadał powiatom sprzed reformy administracyjnej z 1975 r. Swoim zasięgiem obejmował tereny komitetów gminnych PZPR w Czemiernikach, Drelowie, Kąkolewnicy, Komarówce Podlaskiej, Międzyrzecu Podlaskim, Ulanie, Wohyniu; Komitetu Miejskiego w Międzyrzecu Podlaskim oraz Komitetu Miejsko-Gminnego w Radzyniu Podlaskim. Materiały archiwalne ROPP w Radzyniu Podlaskim przejęto 2 IX 1992 r. wraz z dokumentacją wytworzoną przez Komitet Powiatowy, Gminny, Miejski i Miejsko-Gminny z lat 1950-1989. Dokumentacja miała postać rozsypu. W latach 2007-2008 rozpoznawano przynależność zespołową dokumentacji wchodzącej w skład tego zbioru, a w 2011 r. akta ROPP zostały opracowane w Archiwum Państwowym w Lublinie Oddział w Radzyniu Podlaskim.

1D) okumentacja partii komunistycznej w Polsce z lat 1948-1990 znajduje się w zasobach archiwów państwowych od blisko ćwierćwiecza. Jedynie część z utworzonych z niej zespołów jest już opracowanych. Przeglądając spisy zespołów archiwalnych archiwów państwowych w niektórych, natrafimy na nazwę: Rejonowy Ośrodek Pracy Partyjnej (ROPP). W innych znajdziemy ją w zespołach komitetów wojewódzkich PZPR. Celem niniejszego artykułu jest prezentacja tego elementu struktury partii komunistycznej widzianego okiem archiwisty, poprzez opisanie jego dziejów ustrojowych oraz wytworzonej przezeń dokumentacji. Naszym przykładem laboratoryjnym będzie ROPP w Radzyniu Podlaskim. W realizacji podjętego zadania wpierw spróbujemy określić, czym w ogóle był ten element systemu biurokratycznego partii komunistycznej w Polsce, charakterystyczny dla ostatniej dekady jej istnienia. Wydaje się, że najlepiej będzie dojść do zamierzonego celu, rozpoczynając od prezentacji zadań ROPP.

Rejonowe ośrodki pracy partyjnej powołano do istnienia w styczniu $1982 \mathrm{r}$. na podstawie decyzji Sekretariatu Komitetu Centralnego PZPR z 8 XII 1981 r., co wiązało się z przegrupowaniem i uporządkowaniem zadań partii komunistycznej, związanych z nową sytuacją społeczno-polityczną, która miała po- 
jawić się po wprowadzeniu stan wojennego. Zadania ROPP miały koncentrować się wokół:

- usprawnienia kierowania instancjami I stopnia,

- integracji aktywu partyjnego pracującego w terenie,

- usprawnienia przepływu informacji „w teren i z terenu”,

- umacniania funkcji kontrolnych komitetu wojewódzkiego,

- koordynowania współdziałania podstawowych organizacji partyjnych (POP) z organizacjami społecznymi i gospodarczymi,

- utrzymania stałego kontaktu POP z komitetami terenowymi partii,

- usprawniania działalności propagandowej ${ }^{1}$.

Normatywy organizacyjne PZPR określały funkcje ROPP jako doradcze i koordynacyjno-kontrolne wobec wszystkich instancji funkcjonujących na swoim terenie w trzech zasadniczych sferach: organizacyjnej, ideologicznej i propagandowej oraz społeczno-gospodarczej. W sprawach wewnątrzpartyjnych miało to oznaczać:

- pomoc w planowaniu i organizowaniu pracy partyjnej oraz realizacji zadań bieżących terenowym instancjom partyjnym;

- współpracę z członkami władz wojewódzkich partii, którzy na co dzień funkcjonowali w terenie;

- przekazywanie do organizacji partyjnych stopnia podstawowego, czyli szczebla gminnego, decyzji KC i KW, a także bieżącej informacji wewnątrzpartyjnej; co miało dotyczyć także komitetów zakładowych dużych zakładów pracy;

- przekazywanie do KW uwag i spostrzeżeń, które wynikały z kontaktów z terenowymi działaczami partii;

- przekazywanie do instancji wojewódzkiej ocen sytuacji społeczno-politycznej i gospodarczej, wniosków oraz informacji o odbytych i planowanych zebraniach POP, egzekutyw, plenów i naradach;

- udział pracowników ROPP w posiedzeniach plenarnych i egzekutyw komitetów z terenu własnego działania, w zebraniach POP-ów, a także analizowanie na ich podstawie sytuacji społecznej, politycznej i gospodarczej;

- reagowanie na przypadki łamania statutu PZPR, nieprzestrzeganie

1 Zasady funkcjonowania Rejonowych Ośrodków Pracy Partyjnej w województwie bialskopodlaskim, 1984, Archiwum Państwowe w Lublinie Oddział w Radzyniu Podlaskim (dalej APLOR), Rejonowy Ośrodek Pracy Partyjnej w Radzyniu Podlaskim [1975-1981] 1982-1989 (dalej ROPP), sygn. 1, s. 134. 
uchwał instancji partyjnych i przeciwdziałanie im;

- stałą kontrolę systematyki zebrań POP, poprawności pracy kancelaryjnej i stanu dokumentacji wytworzonej przez poszczególne podmioty struktury partii komunistycznej, a w przypadku niedociągnięć i błędów w tym zakresie - udzielanie instruktażu i pomoc w przywróceniu poprawności w tym względzie;

- kontrolę opłacania składek partyjnych przez członków PZPR, co należało bezpośrednio do obowiązków instruktora ds. składek;

- prowadzenie ewidencji partyjnej, zabezpieczenie komitetów w druki ewidencyjne oraz prowadzenie sprawozdań statystycznych;

- zorganizowanie przy ROPP grupy aktywu, czyli najbardziej zaangażowanych w działalność organizacyjną, nieetatowych członków partii komunistycznej danego terenu, którzy mieli uczestniczyć w zebraniach POP i animować ich działalność swoim autorytetem².

Sfera określona literalnie jako ,ideologiczna i propagandowo-agitacyjna", którą dzisiaj nazwalibyśmy działalnością public relations, stawiała przed ROPP takie zadania jak:

- organizowanie szkoleń wykładowców dla potrzeb POP i organizacji I stopnia;

- stworzenie rejonowej grupy lektorów i seminarzystów do prowadzenie działalności szkoleniowych;

- szkolenie kandydatów PZPR;

- szkolenie sekretarzy POP;

- organizowanie spotkań z lektorami KC i KW;

- koordynowanie działalności ideologicznej i agitatorskiej, dystrybucja materiałów propagandowych i informacji otrzymywanych z instancji wyższych i własnych;

- współpracę z jednostkami wojskowymi, zwłaszcza w zakresie możliwości wykorzystania kadry oficerskiej dla propagandowych celów partii komunistycznej;

- utworzenie przy ROPP filii bibliotek Wojewódzkich Ośrodków Kształcenia Ideologicznego, które funkcjonowały w strukturach organizacyjnych $\mathrm{KW}^{3}$.

- organizowanie filii Wieczorowego Uniwersytetu Marksizmu-Leninizmu i naboru słuchaczy;

\footnotetext{
2 Tamże, s. 136-137.

3 Tamże, s. 137.
} 


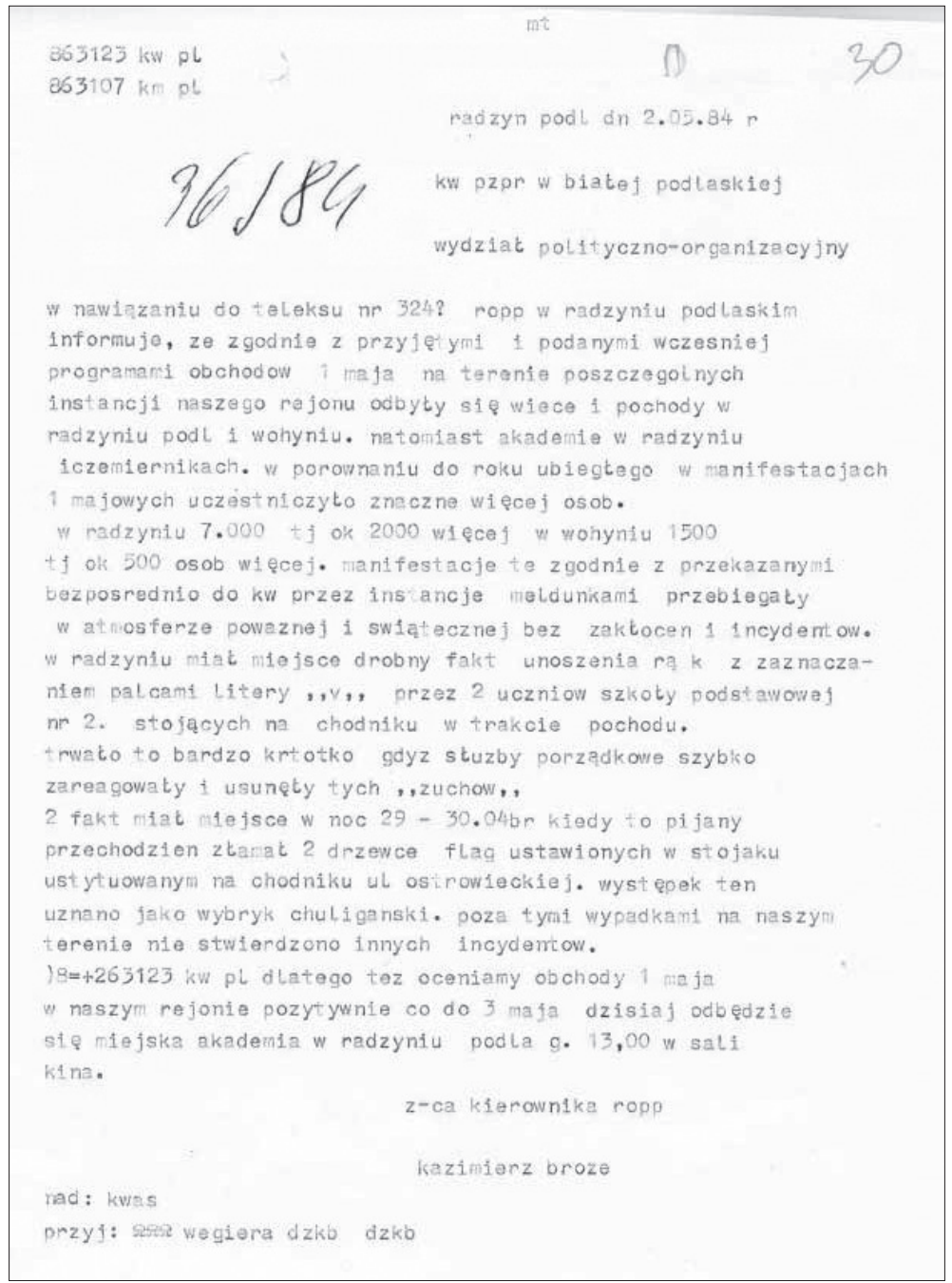

Fot. 1. ROPP jako przekaźnik informacji pionowej (w dół i w górę) Raport teleksowy ROPP w Radzyniu Podlaskim z meldunkiem do KW PZPR w Białej Podlaskiej o przebiegu obchodów święta 1 Maja w Radzyniu Podlaskim w 1984 r.

Źródło: APLOR, ROPP, sygn. 13, s. 30. 
W działalności społeczno-polityczno-gospodarczej zadania ROPP koncentrowały się wokół:

- wspierania i upowszechniania tych działań, które służyć miały podnoszeniu efektywności gospodarczej, a w zasadzie nadzorem nad prowadzeniem zainicjowanej w latach 80. XX w. kolejnej w PRL reformy gospodarczej;

- promowania i inicjowania pomocy komitetów PZPR i administracji państwowej prokomunistycznych organizacji społecznych (Patriotyczny Ruch Odrodzenia Narodowego, Towarzystwo Przyjaźni Polsko-Radzieckiej, Towarzystwo Wiedzy Powszechnej itp.);

- współdziałania z organizacjami społeczno-gospodarczymi w zakresie rozpowszechniania informacji o nowych decyzjach, rozwiązaniach technicznych i organizacyjnych ${ }^{4}$.

Czym zatem były ROPP? Wydaje się, że to kolejny szczebel niedookreślonych podmiotów w magmowatej strukturze partii komunistycznej, tworzącej ową „pokrętną biurokrację”5, będącą z kolei kreatorką „historii ukrytej”, gdzie decyzje podejmują nieliczne, niesprecyzowane bliżej gremia ${ }^{6}$. Oto bowiem mamy rozbudowaną strukturę partii sprawującej totalną władzę, dzięki scentralizowanej strukturze podporządkowującej niższe instancje partyjne wyższym, dążącą do poddania swej kontroli praktycznie każdej dziedziny życia. Władza skupiona była w KC, a realizowała się za pośrednictwem ogniw terenowych organizacji, aż do najniższych komórek PZPR, które oglądane z zewnątrz imponują przepychem i emanują swoistą magią władzyํㄱ, lecz w rzeczywistości stanowią atrapy, w których mamy do czynienia z dwudziestoczterogodzinnym teatrem, gdyż faktyczne decyzje zapadały poza oficjalnymi organami, a ich nominalna samodzielność była mocno ograniczona ${ }^{8}$.

Być może stąd takie zróżnicowanie w efektach rozpoznania przynależności zespołowej materiałów archiwalnych tych podmiotów w poszczególnych archiwach państwowych. Przepisy wewnątrzpartyjne jednoznacznie stwierdzały, że ROPP „nie mogą przejmować statutowych uprawnień władz w terenie”9.

4 Tamże, s. 138.

5 J. Staniszkis, Antropologia władzy, Warszawa 2009, s. 197.

6 J. Karpiński, Wykres goraczki. Polska pod rządami komunistycznymi, Lublin 2001, s. 42-43.

7 J. Staniszkis, dz. cyt., s. 198.

8 Zob. M. T. Korejwo, PZPR na Warmii i Mazurach 1948-1990, Olsztyn 2013, s. 13-19 .

9 APLOR, ROPP, sygn. 1, s. 136. 
Zważywszy na komunistyczną praktykę tzw. centralizmu demokratycznego, stwierdzenie to dosyć stanowcze, jednocześnie oddające istotę nieprzystawalności normatywów (także dotyczących spraw własnych partii) PRL-owskich do praktyki funkcjonowania, którą charakteryzowała zazwyczaj fasadowość. Tymczasem stwierdzenie z dalszej części tego samego dokumentu, że ROPP „nie powinny wyręczać wybieralnego aktywu w wypełnianiu swoich powinności”"10, takiej stanowczości już w nie zawiera i zawierać nie mogło, bo stawałoby naprzeciw codzienności partyjnej, czyli faktycznego sterowania przez instancje wyższe komitetami niższego stopnia.

ROPP nie wchodziły w skład wybieralnych organów statutowych PZPR, lecz - jak już wspomniano - stanowiły biurokratyczną strukturę „doradczo-koordynacyjną" wobec instancji stopnia podstawowego (komitety miejskie, miejsko-gminne, zakładowe i podstawowe organizacje partyjne). Funkcjonowały one na prawach terenowych wydziałów komitetów wojewódzkich partii $^{11}$, a do ich głównych prerogatyw należało kierowanie instancjami I stopnia, integracja aktywu partyjnego, usprawnienie przepływu informacji (w tym o nastrojach społeczeństwa i sytuacji społeczno-gospodarczej), umocnienie funkcji kontrolnej władz zwierzchnich, utrzymywanie ciągłego kontaktu z POP i poszczególnymi instancjami partii, usprawnienie i organizacja działalności propagandowej partii ${ }^{12}$.

\section{Tamże.}

11 ROPP do końca ich istnienia towarzyszyła zawsze pewna doza strukturalnego niedookreślenia, co spowodowane było dużemu zróżnicowaniu organizacyjnemu w obrębie poszczególnych wojewódzkich organizacji PZPR. Dosyć szybko zauważyła ten problem Centralna Komisja Rewizyjna PZPR, która w 1983 r. sugerowała potrzebę centralnego uregulowania tych kwestii i proponowała podporządkowanie ROPP egzekutywom komitetów wojewódzkich, by w ten sposób funkcjonowały one jako wydziały terenowe KW. Tak też te podmioty traktowano, acz bardziej w sposób umowny niźli usankcjonowany prawnie. Zob. Ocena działalności rejonowych ośrodków pracy partyjnej, grudzień 1983, APLOR, ROPP, sygn. 1, s. 141 oraz Formy i metody pracy instancji wojewódzkiej, podstawowych i ROPP woj. bialskopodlaskiego, 1984, APLOR, ROPP, sygn. 1, s. 76.

${ }^{12} \mathrm{~W}$ tym miejscu warto zwrócić uwagę na związki ROPP z rejonami ewidencji partyjnej, które powołane zostały do istnienia w terenie (przeważnie w byłych miastach powiatowych) w 1975 r. w związku z pojawieniem się w strukturze organizacyjnej PZPR wielu nowych komitetów wojewódzkich. Ich celem miało być prowadzenie dokumentacji ewidencji personalnej, sporządzanie miesięcznych i kwartalnych sprawozdań statystycznych oraz weryfikacja liczby członków figurujących w ewidencji z rzeczywistością. Zadania rejonów ewidencji partyjnej można określić jako biurokratycznie organizujące personalne i członkowskie zagadnienia przynależności do partii komunistycznej w terenie. Faktycznie stanowiły część komitetów wojewódzkich, 
Na terenie działania Komitetu Wojewódzkiego Polskiej Zjednoczonej Partii Robotniczej w Białej Podlaskiej ROPP-y utworzono w Białej Podlaskiej, Łosicach, Parczewie i Radzyniu Podlaskim, a obszar ich działania odpowiadał mniej więcej powiatom sprzed reformy administracyjnej z 1975 r. ROPP w Radzyniu Podlaskim swoim zasięgiem obejmował tereny Komitetów Gminnych w: Czemiernikach, Drelowie, Kąkolewnicy, Komarówce Podlaskiej, Międzyrzecu Podlaskim, Ulanie, Wohyniu; Komitetu Miejskiego w Międzyrzecu Podlaskim oraz Komitetu Miejsko-Gminnego w Radzyniu Podlaskim.

Na czele ROPP stał kierownik (w randze kierownika wydziału KW) odpowiadający za całokształt pracy ośrodka, którego personel stanowili:

- zastępca kierownika $\mathrm{w}$ randze zastępcy kierownika wydziału KW;

- instruktor ds. organizacyjno-szkoleniowych, społeczno-samorządowych i rolnych (do jego obowiązków należało organizowanie narad i szkoleń aktywu i sekretarzy POP, współpraca z organizacjami społecznymi, koordynacja pracy POP, utrzymywanie kontaktu z jednostkami administracji państwowej);

- instruktor ds. ewidencji (prowadzenie ewidencji partyjnej, zaopatrzenie instancji partyjnych $\mathrm{w}$ druki ewidencyjne, sporządzanie statystyk i analiz);

- instruktor ds. składek (naliczanie i opłacanie składek, pomoc w prowadzeniu spraw finansowo-gospodarczych instancji podstawowych);

- pracownik techniczny (obsługa teleksu, małej poligrafii, maszynopisanie i wykonywanie prac administracyjno-biurowych) ${ }^{13}$.

lecz z powodu trudności lokalowych w nowo powołanych siedzibach województw, tymczasowo miały być ekspozyturami KW w terenie w zakresie ewidencji partyjnej, K. Paszek, P. Snoch, Akta rejonów ewidencji partyjnej $w$ zasobie archiwum Państwowego $w$ Katowicach, [w:] Partia komunistyczna w Polsce. Struktury - ludzie - dokumentacja, red. D. Magier, Lublin-Radzyń Podlaski 2012, s. 630. Po utworzeniu ROPP w ich strukturze znalazły się dotychczasowe rejony ds. ewidencji partyjnej, składek czy gospodarki wewnątrzpartyjnej danego terenu, K. Chylińska, Inwentarz zespołu archiwalnego Rejonowy Ośrodek Pracy Partyjnej w Bartoszycach, Archiwum Państwowe w Olsztynie, 2003, https://www.archivesportaleurope.net/ead-display/-/ead/pl/aicode/PL-42/type/fa/id/PL-42-1305_SLASH_0 (dostęp: 9 IV 2016 r.) To właśnie wydaje się przyczyną anteriorów (dokumentacja dotycząca stanu organizacyjnego partii, składek członkowskich, szkoleń partyjnych) często występujących w tych zespołach.

13 APLOR, ROPP, sygn. 1, s. 134-135. 


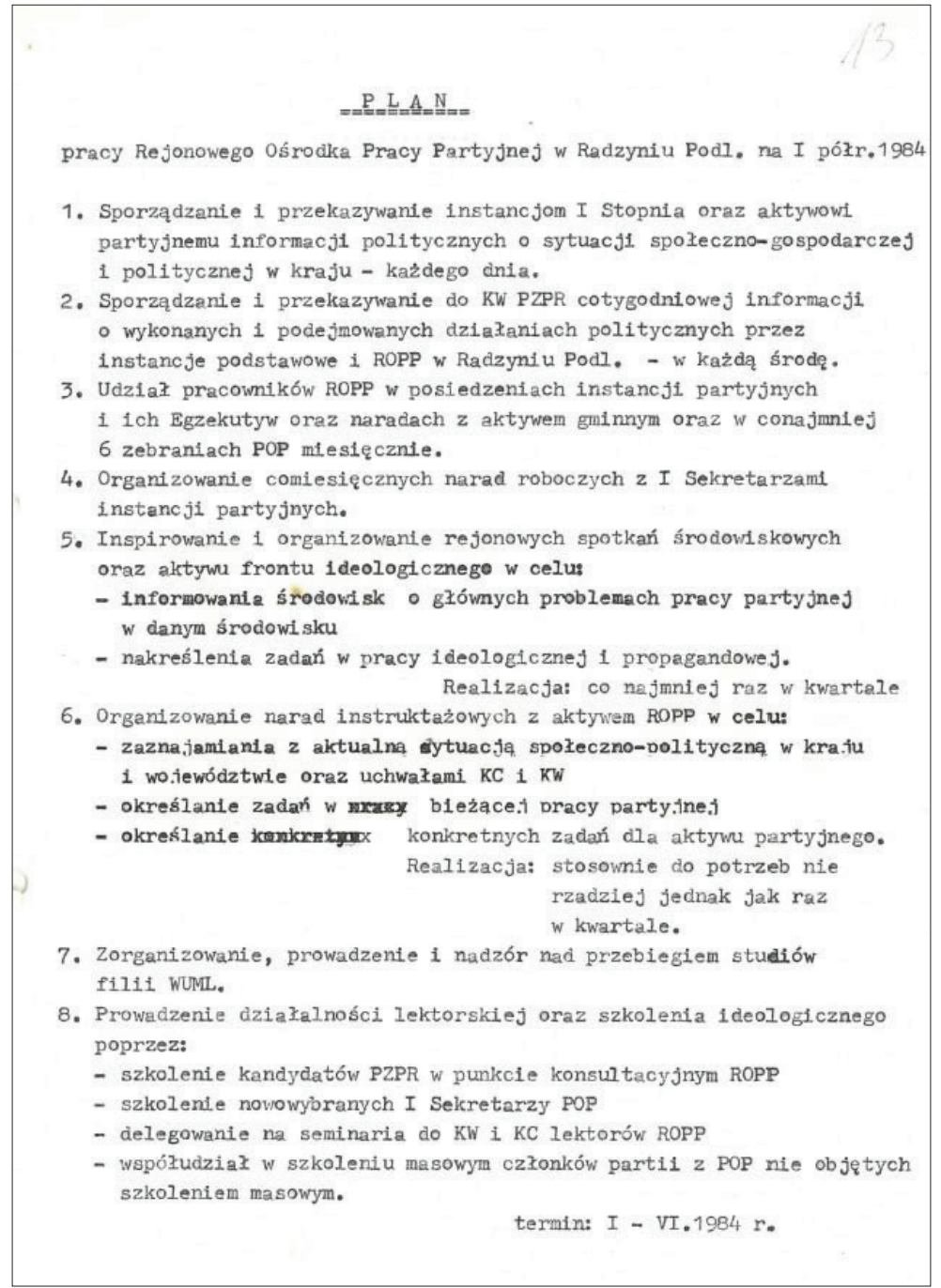

\section{Fot. 2. Przykładowy plan działania ROPP w Radzyniu Podlaskim}

Źródło: APLOR, ROPP, sygn. 2, s. 13.

Bezpośrednie zwierzchnictwo nad ROPP sprawowali sekretarze KW, w zależności od tematyki zadań, ocena zaś z ich działalności przedstawiana była raz w roku na Egzekutywie KW oraz podczas wojewódzkich konferencji sprawozdawczych i sprawozdawczo-wyborczych. 
Swoje funkcje wykonywał ROPP przy pomocy aktywu partyjnego. Z analizy udokumentowanej działalności radzyńskiej placówki wynika, że zagadnienie pozyskiwania wartościowego dla partii komunistycznej aktywu partyjnego w terenie było jednym z jej istotniejszych zadań. Aktyw powoływany był przez kierownika ośrodka spośród członków partii - pracowników instytucji i podmiotów, najlepiej obejmujących zasięgiem działania więcej niż jedną terenową jednostkę administracyjną państwa (obszar ponadgminny). W ten sposób osiągnąć zamierzano równomierne obciążenie zadaniami większej liczby członków partii komunistycznej ${ }^{14}$. Aktyw ROPP skierowany miał być przede wszystkim do pomocy działalności POP w zakresie najpowszechniejszych szkoleń: ustawicznego szkolenia partyjnego i szkolenia kandydatów na członków partii komunistycznej ${ }^{15}$. Rekrutacja aktywu odbywała się poprzez rekomendacje do macierzystej POP kandydata na członka aktywu (każdy członek partii komunistycznej, bez względu na zajmowane stanowisko w partyjnej hierarchii, musiał być członkiem określonej organizacji podstawowej) z prośbą o skierowanie do określonego zadania partyjnego w ramach pracy w aktywie. ROPP cyklicznie informował również rekomendujące POP o postępach członka aktywu w realizacji powierzonego zadania ${ }^{16}$.

Na czele ROPP w Radzyniu Podlaskim stał Julian Dobrowolski; funkcję zastępcy kierownika piastował Kazimierz Brożek, który od 1 XII 1986 r. został

${ }^{14}$ Istota tego zabiegu polegała na przerwaniu dosyć powszechnej praktyki, że „jeden tow[arzysz] pełni kilka funkcji partyjnych i często nie jest w stanie wywiązać się z powierzonych". Formy i metody pracy instancji wojewódzkiej, podstawowych i ROPP woj. bialskopodlaskiego, 1984.

15 Powołanie ROPP porządkowało na nowo funkcjonowanie komunistycznego procesu kształcenia kadr i działalności propagandowej w obrębie wojewódzkiej organizacji PZPR. W latach 70. i 80. XX w. w PZPR ukształtowany został w miarę przejrzysty system pracy szkoleniowej, którego szczegółowe założenia formułowane były w uchwalanych co roku przez Sekretariat KC, opartych na podobnych i każdorazowo lekko jedynie modyfikowanych wytycznych, które z kolei realizowane były przez komitety wojewódzkie w programach szkolenia partyjnego obejmującego wszystkie jego przejawy w danym roku szkoleniowym. Rok szkoleniowy - na wzór życia szkolnego czy akademickiego - rozpoczynał się jesienią a kończył wiosną, obejmował zatem miesiące dwóch różnych lat kalendarzowych. Na terenie województwa plan szkoleniowy przewidywał następujące formy kształcenia: szkolenia kandydatów partii, szkolenia masowe, szkolenia aktywu partyjnego, szkolenia środowiskowe, lektorat, więcej zob. D. Magier, System biurokratyczny Polskiej Zjednoczonej Partii Robotniczej w województwie bialskopodlaskim w latach 1975-1990, Siedlce 2013, s. 101.

${ }^{16}$ Formy i metody pracy instancji wojewódzkiej, podstawowych i ROPP woj. bialskopodlaskiego, 1984. 
kierownikiem ośrodka. Jeśli chodzi o strukturę wewnętrzną, radzyński ROPP składał się z trzech sekcji:

- pracy ideologicznej i wewnątrzpartyjnej ${ }^{17}$;

- ekonomicznej ${ }^{18}$;

- rolnej ${ }^{19}$.

W pracach sekcji uczestniczyło od trzech do pięciu osób.

Przy ROPP w Radzyniu Podlaskim usytuowana była filia Wieczorowego Uniwersytetu Marksizmu-Leninizmu (WUML) - struktura szkoleniowa prowadząca kursy ideologiczne dla kadry nomenklaturowej. W radzyńskim WUML prowadzono Roczne Studium Nauk Społecznych dla aktywu funkcyjnego, przyjmujące na jeden kurs 20-30 słuchaczy ${ }^{20}$.

Przy ROPP w Radzyniu Podlaskim funkcjonowała także Inspekcja Robotniczo-Chłopska - organ kontrolny, którego zadaniem była walka z tzw. spekulacją towarem, czyli hurtowym wykupem towaru i odsprzedawaniem go po wyższej cenie. W teorii była to organizacja społeczna, w praktyce w jej skład wchodził aparat partii komunistycznej, pracownicy Prokuratury Rejonowej i Rejonowego Urzędu Spraw Wewnętrznych.

ROPP w Radzyniu Podlaskim zakończył istnienie wraz z samorozwiązaniem się PZPR 29 I $1990 \mathrm{r}$.

Materiały archiwalne ROPP w Radzyniu Podlaskim przejęto do Archiwum Państwowego w Lublinie Oddział w Radzyniu Podlaskim 2 IX 1992 r. wraz z dokumentacją wytworzoną przez Komitet Powiatowy, Gminny, Miejski i Miejsko-Gminny z lat 1950-1989, zdeponowaną w radzyńskiej siedzibie partii. Z powodu braku jakichkolwiek środków ewidencyjnych uformowano tymczasowe jednostki aktowe, które wpisano jako zespół (właściwie zbiór) nr 278: Komitet Miejski Polskiej Zjednoczonej Partii Robotniczej w Radzyniu Podlaskim. W latach 2007-2008 rozpoznawano przynależność zespołową dokumentacji wchodzącej w skład tego zbioru, wydzielając (księga przesunięć międzyzespołowych nr 64/2009) dokumentację wytworzoną przez ROPP jako

17 Członkowie: Stanisław Koprianiuk, Eugeniusz Klewek, Kazimierz Zwoliński, Edward Wrotniak, Stanisław Zabielski, Józef Szerszonowicz. Zob. Wykaz aktywu Rejonowego Ośrodka Pracy Partyjnej w Radzyniu Podl., APLOR, ROPP, sygn. 1, s. 74.

18 Członkowie: Witold Kowalczyk, Jan Brożek, Bogusław Dobrocki, Ryszard Pazurkiewicz, tamże.

19 Członkowie: Witold Pyzik, Andrzej Frąk, Szczepan Skomra, Jacek Wojtuń, Adam Dołęga, tamże.

${ }^{20}$ APLOR, Komitet Wojewódzki Polskiej Zjednoczonej partii Robotniczej w Białej Podlaskiej [1946-1974] 1975-1990, sygn. 146, s. 57-64. 
zespół prosty zamknięty, który zaliczony został do grupy A3, z przeznaczeniem do pełnego opracowania ${ }^{21}$. Na materiał aktowy składają się druki, maszynopisy, rękopisy i kserokopie.

Porządkowanie dokumentacji przeprowadzili w lipcu i sierpniu 2011 r., w ramach praktyk studenckich, Michał Dmitrowicz i Jakub Romaniuk - studenci archiwistyki Katolickiego Uniwersytetu Lubelskiego. W pierwszej kolejności sprawdzono poprawność uformowania jednostek archiwalnych i dokonano niezbędnych korekt $\mathrm{w}$ tym zakresie, przemieszczając dokumentację między jednostkami oraz tworząc nowe i łącząc inne. Pozostawiono w zespole jako anteriora dokumentację z lat 1975-1981, która ewidentnie stała się sukcesją komórek organizacyjnych KW zajmujących się działaniami, jakie od 1982 r. weszły do zadań ROPP (np. składki partyjne, kopie list płac), i stanowiła podstawę jego funkcjonowania. Usystematyzowano dokumentację w obrębie jednostek w kolejności chronologicznej i spaginowano. Następnie akta przełożone zostały do bezkwasowych teczek zabezpieczających, na których naniesiono opisy w tym nowe tytuły jednostek.

W związku z tym, że na obwolutach oraz dokumentacji brak jakichkolwiek znaków kancelaryjnych oraz znamion stosowania konkretnego systemu kancelaryjnego, w ramach archiwalnego opracowania nadano teczkom nowy układ rzeczowo-chronologiczny. Jednostki archiwalne zespołu zostały poddane segregacji w ramach sześciu serii (ostateczny układ zespołu pokazuje tabela 1). Inwentaryzacja została przeprowadzona w Zintegrowanym Systemie Informacji Archiwalnej (ZoSIA), z którego wydruk stanowi inwentarz książkowy zespołu. Zespół uznano za opracowany decyzją Komisji Metodycznej Archiwum Państwowego w Lublinie i Zamościu 4 X 2011 r. Inwentarz zespołu dostępny jest na portalu internetowym Szukajwarchiwach.pl.

${ }^{21}$ Na mocy Decyzji nr 20 Naczelnego Dyrektora Archiwów Państwowych z dnia 10 grudnia 2002 r. w sprawie wprowadzenia wskazówek metodycznych dotyczących uproszczonego opracowania zasobu archiwalnego przechowywanego w archiwach państwowych wprowadzono podział zasobu archiwów państwowych na trzy grupy (A1, A2 i A3), przy czym zaliczenie do grupy drugiej i trzeciej może skutkować zastosowaniem tzw. uproszczonym opracowaniem wg wskazówek stanowiących załącznik do w/w decyzji. Zob. http://archiwalna.archiwa.gov.pl/pl/prawo/70-akty-normatywnenaczelnego-dyrektora-archiwow-panstwowych.html (dostęp: 11 IV 2016 r.). 
Tabela 1. Układ i zawartość akt zespołu archiwalnego Rejonowy Ośrodek Pracy Partyjnej w Radzyniu Podlaskim

\begin{tabular}{|c|c|c|c|}
\hline Nazwa serii & sygnatura & $\begin{array}{l}\text { Daty } \\
\text { skrajne }\end{array}$ & Zawartość \\
\hline Organizacja & $1-7$ & 1982-1988 & $\begin{array}{l}\text { wytyczne, zalecenia i informacje władz } \\
\text { zwierzchnich; zasięg i stan organizacyj- } \\
\text { ny ROPP, protokoły z narad partyjnych; } \\
\text { odciski pieczęci komitetów instancji } \\
\text { podstawowych PZPR, inwentaryzacja; } \\
\text { wypożyczanie sprzętu technicznego } \\
\text { należącego do KW; ewidencja i doku- } \\
\text { mentacja urlopów pracowników partii; }\end{array}$ \\
\hline $\begin{array}{l}\text { Praca } \\
\text { partyjna }\end{array}$ & $8-19$ & 1980-1988 & $\begin{array}{l}\text { notatki z zebrań POP w } 1980 \text { r.; mel- } \\
\text { dunki o sytuacji w terenie, oceny pracy } \\
\text { zespołów radnych PZPR; informacje } \\
\text { o pracy wśród młodzieży, teleksy wy- } \\
\text { syłane do i z ROPP; notatki i meldunki } \\
\text { z przebiegu wyborów do sejmu i rad } \\
\text { narodowych; }\end{array}$ \\
\hline $\begin{array}{l}\text { Wieczorowy Uniwersytet } \\
\text { Marksizmu-Leninizmu }\end{array}$ & $20-26$ & $\begin{array}{c}{[1975-1981]} \\
1982-1989\end{array}$ & $\begin{array}{l}\text { organizacja; tematyka i rozkłady zajęć; } \\
\text { referaty słuchaczy; podania o przyjęcie, } \\
\text { karty ewidencyjne, indeksy i protokoły } \\
\text { egzaminacyjne listy obecności na za- } \\
\text { jęciach; }\end{array}$ \\
\hline $\begin{array}{l}\text { Inspekcja } \\
\text { Robotniczo-Chłopska }\end{array}$ & 27 & 1985-1988 & $\begin{array}{l}\text { podstawy funkcjonowania, organizacja, } \\
\text { skład i analizy działania; }\end{array}$ \\
\hline $\begin{array}{l}\text { Ewidencja składek } \\
\text { członkowskich }\end{array}$ & $28-66$ & $\begin{array}{c}{[1975-1981]} \\
1982-1988\end{array}$ & $\begin{array}{l}\text { książki ewidencyjne i listy składek } \\
\text { miesięcznych }\end{array}$ \\
\hline $\begin{array}{l}\text { Wyciągi } \\
\text { z list płac }\end{array}$ & $67-71$ & $\begin{array}{c}{[1976-1981]} \\
1982-1988\end{array}$ & listy płac pracowników ROPP \\
\hline
\end{tabular}

Źródło: D. Magier, Inwentarz do zespołu akt Rejonowy Ośrodek Pracy Partyjnej w Radzyniu Podlaskim [1975-1981] 1982-1989, Radzyń Podlaski 2011 [mps w APLOR].

Z racji pełnionych przez omawiane jednostki funkcji, na podstawie materiałów archiwalnych ROPP w Radzyniu Podlaskim, stwierdzić można, że co prawda wytworzona przez nie dokumentacja częściowo powiela informacje zawarte w aktach bardziej syntetycznej treści znajdujących się w zespołach komitetów wojewódzkich PZPR (informacje okólne i organizacyjne przekazywane do instancji niższych), jednocześnie jednak kumuluje i podaje w przetworzonej formie te, które docierały doń z dołu i były przekazywane w górę hierarchii organizacyjnej. Większość akt niesie zatem informację niepowta- 
rzalną, dającą z jednej strony bardziej szczegółowe dane o funkcjonowaniu partii komunistycznej w terenie, $\mathrm{z}$ drugiej szersze spojrzenie na wewnątrzorganizacyjną rzeczywistość jej codziennego działania. Pod tym względem jej wartość badawcza wydaje się bezdyskusyjna.

Udostępnienie badaczom oraz szerszemu kręgowi odbiorców każdego nowo opracowanego zespołu archiwalnego - kolejnego elementu skomplikowanej struktury partii komunistycznej w Polsce, staje się okazją do podjęcia dyskusji o związkach genetycznych dokumentacji podmiotów funkcjonujących we wszechobecnej w realiach PRL sieci organizacyjnej PZPR. W niniejszej pracy dotyczy to przede wszystkim wątpliwości związanych z niedookreśleniem tworu, jakim był ROPP. Niewątpliwie był aktotwórcą, czy stanowił jednak również twórcę zespołu archiwalnego?22 Abstrahując od odpowiedzi na to pytanie, stwierdzić trzeba, że z pewnością jego dokumentacja rzuca nowe światło na wciąż nieopisaną historię PZPR.

\section{Archiwalia}

Archiwum Państwowe w Lublinie Oddział w Radzyniu Podlaskim

- Komitet Wojewódzki Polskiej Zjednoczonej partii Robotniczej w Białej Podlaskiej [1946-1974] 1975-1990

- Rejonowy Ośrodek Pracy Partyjnej w Radzyniu Podlaskim [1975-1981] 1982-1989

\section{Literatura}

Chylińska K., Inwentarz zespołu archiwalnego Rejonowy Ośrodek Pracy Partyjnej w Bartoszycach, Olsztyn 2003, https://www.archivesportaleurope.net/ead-display/-/ ead/pl/aicode/PL-42/type/fa/id/PL-42-1305_SLASH_0 (dostęp: 9 IV 2016 r.).

Magier D., Inwentarz zespołu akt Rejonowy Ośrodek Pracy Partyjnej w Radzyniu Podlaskim z lat [1975-1981] 1982-1989, Radzyń Podlaski 2011 [mps w Archiwum Państwowym w Lublinie Oddział w Radzyniu Podlaskim].

Magier D., System biurokratyczny Polskiej Zjednoczonej Partii Robotniczej w województwie bialskopodlaskim w latach 1975-1990, Siedlce 2013.

${ }^{22}$ Polska terminologia archiwalna rozróżnia te dwa pojęcia. Aktotwórcą określa instytucję lub osobę fizyczną, w wyniku działalności, której powstają akta. Twórcą zespołu - jednostkę organizacyjną posiadającą określony zakres działania i samodzielność organizacyjną, działającą z reguły w oparciu o właściwe dla siebie normy prawne. Należy to zatem rozumieć w ten sposób, że każdy twórca zespołu jest aktotwórcą, ale nie każdy aktotwórca jest twórcą zespołu, Polski słownik archiwalny, red. W. Maciejewska, Warszawa 1974, s. 17 i 83. 
Karpiński J., Wykres gorączki. Polska pod rządami komunistycznymi, Lublin 2001.

Korejwo M. T., PZPR na Warmii i Mazurach 1948-1990, Olsztyn 2013.

Paszek K., Snoch P., Akta rejonów ewidencji partyjnej w zasobie archiwum Państwowego w Katowicach, [w:] Partia komunistyczna $w$ Polsce. Struktury - ludzie - dokumentacja, red. D. Magier, Lublin-Radzyń Podlaski 2012.

Polski słownik archiwalny, red. W. Maciejewska, Warszawa 1974.

Staniszkis J., Antropologia władzy, Warszawa 2009.

\section{Summary}

Local Party Labor Center in Radzyń Podlaski (1982-1989) - an element of the organization structure of the Polish United Workers' Party, documents creator, archival fonds

Local Party Labor Centers were created in January 1982, in connection with reorganization of assignments of the Polish United Workers' Party in the new socio-political situation after the declaration of martial law in Poland. The article presents this element of the complex bureaucratic structure, holding dictatorial authority in the party, by describing its political history and documentary legacy from the archival perspective. The laboratory example is the Local Party Labor Center in Radzyń Podlaski. The author set himself a task to describe what was the role of the Center in the Polish communist party - a formation so characteristic for the last decade of existence of the Party. The LPLCs were not elective statutory bodies of the PUWP, but they were a bureaucratic structure, that served an advisory and coordination function towards basic levels of the communist party. The LPLC in Radzyń Podlaski was one of four such formations created in the Bielsk Podlaski Voivodeship, and its area of action were counties from the period before the administrative reform in 1975. The scope of the Center were district committees of the PUWP situated in Czemierniki, Drelów, Kąkolewnica, Komarówka Podlaska, Międzyrzec Podlaski, Ulan, Wohyń; the Town Committee in Międzyrzec Podlaski and the Town-Distric Committee in Radzyń Podlaski. Archival materials of the LPLC in Radzyń Podlaski were transmitted on September 2, 1992 with documentation created by the County, the District, the Town and the Town-Disctrict Committee from 1950 to 1989. The materials were scattered. In 2007-2008 fonds of this documentation were recognized and in 2011 the materials of the LPLC were arranged and described in the State Archive in Lublin, Branch in Radzyń Podlaski. 
